\title{
Activation of ATM/Chk I by curcumin causes cell cycle arrest and apoptosis in human pancreatic cancer cells
}

\author{
RP Sahu', S Batra' and SK Srivastava*,I \\ 'Department of Pharmaceutical Sciences and Cancer Biology Center, School of Pharmacy, Texas Tech University Health Sciences Center, Amarillo, Texas, \\ USA
}

\begin{abstract}
Curcumin has been shown to inhibit the growth of various types of cancer cells; however, at concentrations much above the clinically achievable levels in humans. The concentration of curcumin achieved in the plasma after oral administration in humans was estimated to be around I.8 $\mu \mathrm{M}$. Here, we report that treatment of BxPC-3 human pancreatic cancer cells with a low and single exposure of $2.5 \mu \mathrm{M}$ curcumin for $24 \mathrm{~h}$ causes significant arrest of cells in the G2/M phase and induces significant apoptosis. Immunoblot studies revealed increased phosphorylation of H2A.X at Ser-139 and ChkI at Ser-280 and a decrease in DNA polymerase- $\beta$ level in curcumin-treated cells. Phosphorylation of H2A.X and Chk I proteins are an indicator of DNA damage whereas DNA polymerase- $\beta$ plays a role in the repair of DNA strand breaks. Normal immortalised human pancreatic ductal epithelial (HPDE-6) cells remained unaffected by curcumin treatment. In addition, we also observed a significant increase in the phosphorylation of ChkI at Ser-345, Cdc25C at Ser-216 and a subtle increase in ATM phosphorylation at Ser-1981. Concomitant decrease in the expressions of cyclin B I and CdkI were seen in curcumin-treated cells. Further, curcumin treatment caused significant cleavage of caspase-3 and PARP in BxPC-3 but not in HPDE-6 cells. Silencing ATM/ChkI expression by transfecting BxPC-3 cells with ATM or ChkI-specific SiRNA blocked the phosphorylation of ATM, Chkl and Cdc25C and protected the cells from curcumin-mediated G2/M arrest and apoptosis. This study reflects the critical role of ATM/ChkI in curcumin-mediated G2/M cell cycle arrest and apoptosis in pancreatic cancer cells.

British Journal of Cancer (2009) 1 00, I425 - |433. doi: I 0.1038/sj.bjc.6605039 www.bjcancer.com
\end{abstract}

(c) 2009 Cancer Research UK

Keywords: curcumin; pancreatic cancer; G2/M arrest; DNA damage; ChkI

Pancreatic cancer is the fourth leading cause of cancer-related deaths in the United States (Jemal et al, 2005). The poor prognosis in pancreatic cancer is due to the reduced response of patients to chemotherapy and/or radiation therapy. Curcumin (diferuloylmethane) is a major constituent of turmeric powder, which is extracted from the rhizomes of the plant curcuma longa. Many pharmacological and clinical studies support the fact that curcumin has chemopreventive and antiproliferative activity against a variety of human cancers including pancreatic cancers (Ammon and Wahl, 1991; Li et al, 2004; Lev-Ari et al, 2006; Mitra et al, 2006; Reddy et al, 2006; Wang et al, 2006; Aggarwal et al, 2007; Bachmeier et al, 2007; Hauser et al, 2007; Shankar and Srivastava, 2007; Wahl et al, 2007). In addition, curcumin is also pharmacologically safe as it is a naturally occurring compound used as a food-colouring agent and in traditional medicines to treat various diseases in Asian countries (Ammon and Wahl, 1991; Goel et al, 2008). Epidemiological studies also support the notion that populations from East Asian countries where the consumption of curcumin is high are at a reduced risk to various types of

\footnotetext{
* Correspondence: Dr SK Srivastava, Department of Pharmaceutical Sciences, Texas Tech University Health Sciences Center, School of Pharmacy, Suite I 103, I 406 Coulter Drive, Amarillo, Texas, USA;

E-mail: Sanjay.Srivastava@TTUHSC.edu

Revised 4 March 2009; accepted 19 March 2009
}

cancers including pancreatic cancer (Ammon and Wahl, 1991; Goel et al, 2008) as compared with the populations of Western countries (Mukhopadhyay et al, 2001; Sinha et al, 2003). Previous reports have documented that curcumin has anti-inflammatory, antimicrobial, antioxidative, immunomodulating and antiatherogenic properties (Mukhopadhyay et al, 2001; Miquel et al, 2002; Banerjee et al, 2003). Inhibition of cell growth and induction of apoptosis is the common mechanism by which curcumin shows its anticancer effects. Accumulating evidence suggests the involvement of multiple-signaling pathways by which curcumin causes growth suppression of human cancer cells (Cheng et al, 2001; Hidaka et al, 2002; Bharti et al, 2003; Kim et al, 2003; Shishodia et al, 2003; Blasius et al, 2006; Lev-Ari et al, 2006; Mitra et al, 2006; Park et al, 2006; Tan et al, 2006; Aggarwal et al, 2007; Aoki et al, 2007; Deeb et al, 2007; Fahey et al, 2007; Lin et al, 2007, 2008; Marín et al, 2007; Shankar and Srivastava, 2007; Srivastava et al, 2007; Weir et al, 2007; Binion et al, 2008; Freudlsperger et al, 2008; Ji et al, 2008; Kasinski et al, 2008; Mackenzie et al, 2008; Shankar et al, 2008; Sun et al, 2008). Phase I clinical trials of curcumin demonstrated encouraging chemopreventive effects in patients with high-risk or pre-malignant lesions. It is also non-toxic to humans up to the dose of $8 \mathrm{gday}^{-1}$ (Cheng et al, 2001; Sharma et al, 2004).

Although the anticancer effects of curcumin have been documented in various types of cancers, no evidence is available on curcumin-mediated cell cycle regulation in pancreatic cancer. 
We show herein a novel mechanism by which curcumin causes G2/M cell cycle arrest and apoptosis in pancreatic cancer cells at concentrations that are very close to plasma-achievable concentrations of curcumin in humans. Our studies also identify Chk1 as a novel molecular target of curcumin in pancreatic cancer cells.

\section{MATERIALS AND METHODS}

\section{Chemicals}

Curcumin, RNase A, propidium iodide and antibody against $\beta$ actin were purchased from Sigma-Aldrich (St Louis, MO, USA). Heat inactivated fetal bovine serum and RPMI-1640 medium was obtained from Mediatech Cell Grow (Herndon, VA, USA). Electrophoresis reagents were from Amresco (Solon, OH, USA). Antibodies against phospho-ataxia-telangiectasia-mutated (ATM) (Ser-1981), ataxia-telangiectasia-mutated Rad3 related (ATR) (Ser-428), check point kinase-1 (Chk1) (Ser-345, 317, 296 and 280), check point kinase-2 (Chk2) (Thr-68), cell division cycle (Cdc25C) (Ser-216), H2A.X (Ser-139) as well as against total protein of ATM, ATR, Chk1, Chk2, Cdc25C, Cdk1, CyclinB1, cleaved fragments of caspase-3, poly(ADP-ribose) polymerase (PARP) and human-specific Signal Silence Chk1-SiRNA kit were procured from Cell Signaling Technology Inc. (Danvers MA, USA). Human-specific ATM-SiRNA was procured from Santa Cruz Biotechnology Inc. (Santa Cruz, CA, USA). Transfection reagent (TransIT-TKO) was from Mirus Bio Corporation (Madison, WI, USA), whereas, antibody against DNA polymerase $\beta-1$ was obtained from Lab Vision Corporation (Fremont, CA, USA). Chemicals for cell culture such as penicillin/streptomycin antibiotic mixture (PSN), sodium pyruvate, HEPES buffer, opti-mem I-reduced serum medium were purchased from GIBCO BRL (Carlsbad, CA, USA). Cell death detection apoptosis ELISA kit was the product of Roche Applied Science (Mannheim, Germany), whereas enhanced chemiluminiscence reagent for western blotting was purchased from Perkin Elmer (Waltham, MA, USA).

\section{Cell culture and proliferation assays}

BxPC-3 cells (a well-differentiated epithelial pancreatic adenocarcinoma cell line obtained from a male Caucasian donor having mutant p53 and wild-type K-ras) were obtained from American Type Cell Culture. A monolayer culture of BxPC3 cells was maintained in RPMI-1640 medium supplemented with $10 \%$ fetal bovine serum, $4.5 \%$ glucose, $10 \%$ sodium pyruvate, $10 \%$ HEPES and antibiotics in a humidified incubator with $5 \% \mathrm{CO}_{2}$ and $95 \%$ air. Normal human pancreatic ductal epithelial cells (HPDE-6) were a generous gift from Dr Ming-Sound Tsao (Toronto, Canada). The long-term culture of pancreatic ductal epithelial cells derived from normal and benign adult human pancreata was achieved by infection with a retrovirus containing the E6 and E7 genes of the human papilloma virus 16 (Furukawa et al, 1996; Ouyang et al, 2000). HPDE-6 cells were maintained in keratinocyte-SFM serumfree medium supplemented with $4 \mathrm{~mm}$ L-glutamine and adjusted to contain $0.2 \mathrm{ng} \mathrm{ml}^{-1} \mathrm{EGF}, 30 \mu \mathrm{g} \mathrm{ml}^{-1} \mathrm{BPE}$ and $1 \%\left(\mathrm{vv}^{-1}\right)$ PSN (Furukawa et al, 1996; Ouyang et al, 2000). A stock solution of curcumin was prepared in dimethyl sulfoxide (DMSO), which was subsequently diluted in medium so that the concentration of DMSO was less than $0.1 \%$. BxPC-3 and HPDE- 6 cells were treated with varying concentrations of curcumin for $24 \mathrm{~h}$. The effect of curcumin on survival of BxPC3 cells was determined by Sulforhodamine B assay as described earlier (Zhang et al, 2006; Sahu and Srivastava, 2009). The plates were read at $570 \mathrm{~nm}$ with a Bio Kinetics plate reader EL-800 from BioTek Instrument Inc., (Winooski, VA, USA).

\section{Cell cycle analysis}

The effect of curcumin on cell cycle distribution was assessed by flow cytometry after staining the cells with propidium iodide. Briefly, $0.3 \times 10^{6}$ cells (BxPC-3 and HPDE-6) were plated and allowed to attach overnight. The medium was replaced with fresh complete medium containing the differing concentrations of $(0,2.5,5$ and $10 \mu \mathrm{M})$ curcumin or DMSO. After incubating for specified times, cells were collected using $0.05 \%$ trypsin, washed two times with cold PBS and fixed with ice-cold $70 \%$ ethanol overnight at $4^{\circ} \mathrm{C}$. The cells were then treated with $80 \mathrm{mgl}^{-1}$ RNase A and $50 \mathrm{mgl}^{-1}$ propidium iodide for $30 \mathrm{~min}$ as described earlier (Srivastava and Singh, 2004). The stained cells were analysed using a Coulter Epics XL Flow Cytometer.

\section{Western blot analysis}

BxPC- 3 and HPDE- 6 cells were treated with varying concentrations of curcumin $(0,2.5,5$ and $10 \mu \mathrm{M})$ for $24 \mathrm{~h}$. Whole cell extracts were prepared as described earlier (Zhang et al, 2006; Sahu and Srivastava, 2009). Lysates containing 20-40 $\mu \mathrm{g}$ of proteins were subjected to SDS-PAGE followed by transfer of proteins to a PVDF membrane. After blocking with 5\% nonfat dry milk for $1 \mathrm{~h}$ at RT, membranes were incubated overnight at $4^{\circ} \mathrm{C}$ with the desired primary antibody (1:1000 dilution). Membranes were washed with TBS $0.1 \%$ Tween-20 for 20-30 min followed by incubation in a secondary antibody linked to HRP. Immunoreactive bands were visualised using an enhanced chemiluminescence kit according to the manufacturer's instructions. The same membrane was reprobed with the antibody against $\beta$-actin ( $1: 50000$ dilution) as an internal control for equal protein loading.

\section{Apoptosis determination}

Apoptotic cell death was determined by probing with caspase- 3 and PARP-cleaved antibodies and by cell death detection ELISA kit as described earlier (Shi et al, 2008; Zhang et al, 2008). Cell death detection is based on a quantitative sandwich-enzyme immunoassay principle using monoclonal antibodies directed against DNA and histones. Briefly, BxPC-3 cells were seeded in 96-well plates and transfected either with ATM or Chk1-SiRNA followed by treatment with $2.5 \mu \mathrm{M}$ curcumin for $24 \mathrm{~h}$. The plates were read at $405 \mathrm{~nm}$ against sample and at $490 \mathrm{~nm}$ for blank on EL800 ELISA plate reader, Bio Tek Instruments. Each sample was analysed in triplicate and the average values were subtracted from the background values.

\section{Transfection with ATM or Chk1-SiRNA}

BxPC-3 cells were transiently transfected either with ATM or Chk1-SiRNA to silence constitutive ATM or Chk1 expression. Briefly $0.3 \times 10^{6}$ cells were transfected either with $50 \mathrm{nM}$ ATMSiRNA or $100 \mathrm{~nm}$ Chk1-SiRNA in opti-mem-reduced serum medium using Mirus TransIT-TKO transfection reagent for $24 \mathrm{~h}$. Following transfection, cells were treated with DMSO or curcumin $(2.5 \mu \mathrm{M})$ for $24 \mathrm{~h}$. Transfected cells were either processed for cell cycle or western blot analysis.

\section{Densitometric scanning and statistical analysis}

The intensity of immunoreactive bands was determined using a densitometer (Molecular Dynamics, Minneapolis, MN, USA) equipped with Image QuaNT software. Results are expressed as means \pm s.e.m. of at least two independent experiments, each conducted in triplicate. Data for cell death ELISA and cell cycle were analysed by non-parametric ANOVA followed by Bonferroni's post hoc analysis for multiple comparisons. All statistical calculations were performed using InStat software and GraphPad Prizm 4.0. Differences between control and curcumin treatment were 
analysed by 1-way ANOVA. Differences were considered significant at $P<0.05$.

\section{RESULTS}

\section{Antiproliferative effect of curcumin}

We first determined the optimum dose of curcumin required to inhibit the proliferation of BxPC-3 cells. Treatment of BxPC-3 cells with increasing concentrations of curcumin for $24 \mathrm{~h}$ significantly reduced the survival of cells with an $\mathrm{IC}_{50}$ of $5 \pm 0.5 \mu \mathrm{M}$ (Figure $1 \mathrm{~A}$ ). On the other hand, survival of normal HPDE- 6 cells was minimally affected by curcumin treatment even at concentrations that were highly toxic to $\mathrm{BxPC}-3$ cells.

\section{Curcumin causes G2/M cell cycle arrest}

To gain further insight into the mechanism of the growth inhibitory effects of curcumin, BxPC-3 cells were treated with different concentrations of curcumin and analysed for cell cycle distribution. As shown in Figure 1C, as compared with DMSOtreated cells, $2.5 \mu \mathrm{M}$ curcumin treatment caused significant arrest of cells in the G2/M phase, whereas higher concentrations of curcumin-induced extensive apoptosis. However, curcumin treatment did not cause any change in the cell cycle distribution of normal HPDE-6 cells (Figure 1D).

\section{Curcumin causes DNA damage and induces apoptosis}

To determine the DNA-damaging effect of curcumin, cell lysates were analysed by western blotting. Phosphorylation of H2A.X at Ser-139, Chk1 at Ser-280 and Ser-296 are the indicators of the presence of DNA double-strand breaks. We observed an increased phosphorylation of H2A.X at Ser-139 and Chk1 at Ser-280 (Figure 2A), whereas no phosphorylation of Chk1 at Ser-296 was observed in control and treated cells (data not shown). At the same time, our results show that curcumin treatment decreased expression of DNA polymerase $\beta$ (Figure 2A). DNA polymerase $\beta$ plays a crucial role in the repair of DNA strand break. We also observed an increase in the cleaved fragments of caspase- 3 and PARP in curcumin-treated BxPC-3 cells, indicating apoptosis (Figure 2C). Nevertheless, we did not observe phosphorylation of H2A.X or Chk1 or cleavage of caspase3/PARP by curcumin treatment in HPDE-6 cells (Figure 2B and D).
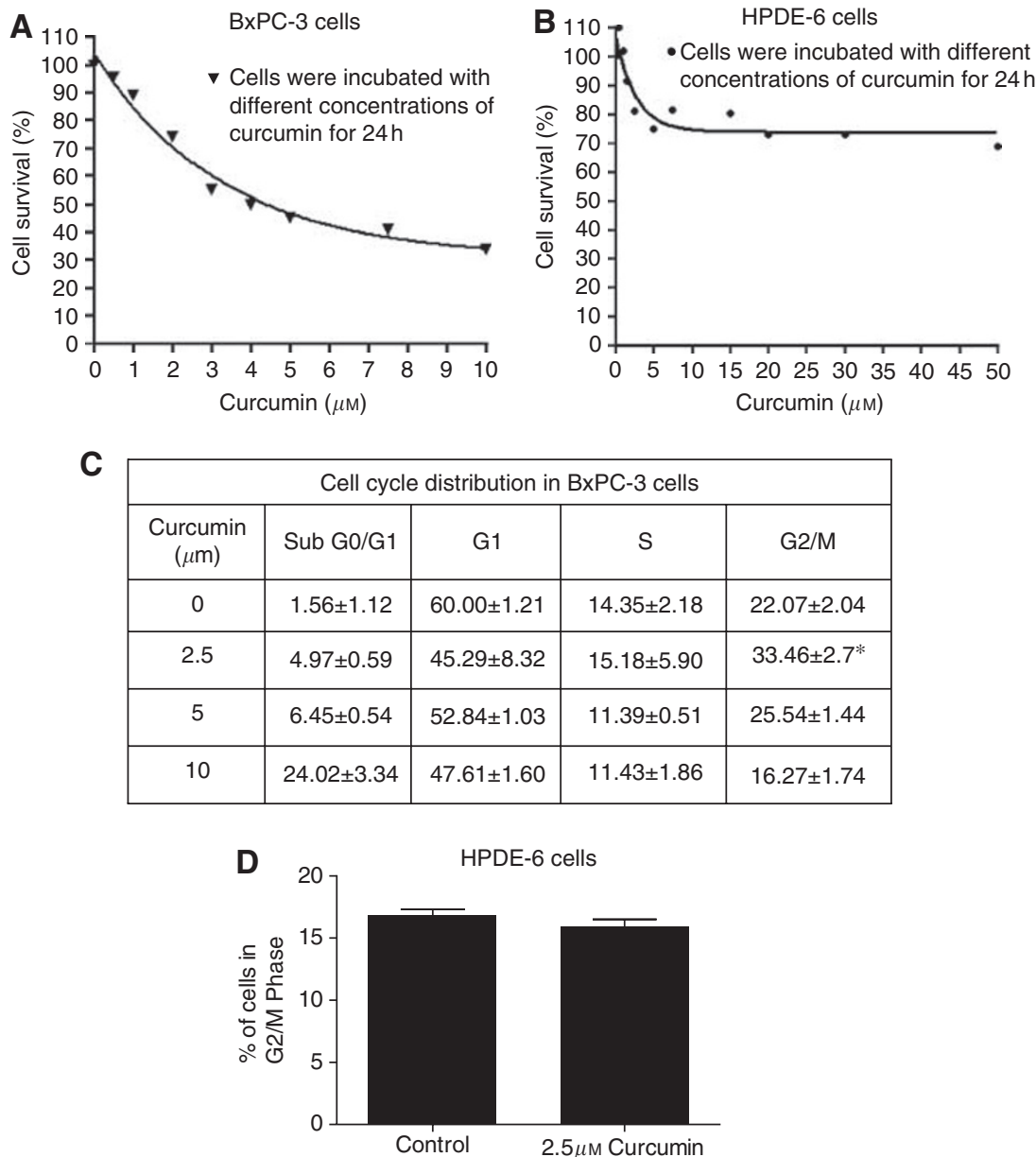

Figure I Effect of curcumin on the proliferation and cell cycle distribution of BxPC-3 and HPDE-6 cells. BxPC-3 human pancreatic cancer cells and normal HPDE-6 cells were treated with different concentrations of curcumin for $24 \mathrm{~h}$. The effect of curcumin on the proliferation of these cells was analyzed by Sulforhodamine B assay. The values are mean \pm s.e.m. of 3 independent experiments (each conducted in triplicate) $(\mathbf{A}$ and $\mathbf{B})$. BxPC-3 and HPDE-6 cells were treated with different concentrations of curcumin and its effect on the cell cycle distribution was evaluated by flow cytometry as described in the Materials and Methods ( $\mathbf{C}$ and $\mathbf{D})$. The values are means \pm s.e.m. of 2 independent experiments (each conducted in triplicate). *Different from control, $P<0.05$. 
A

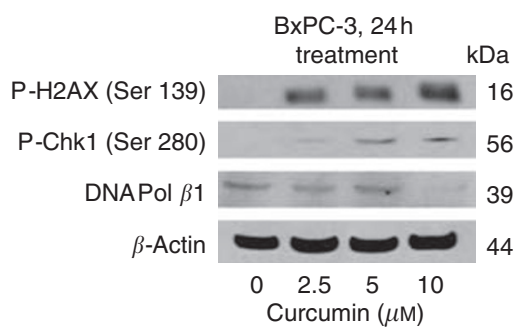

C

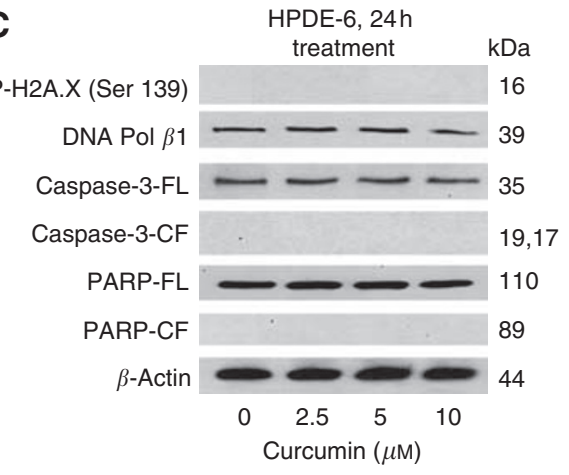

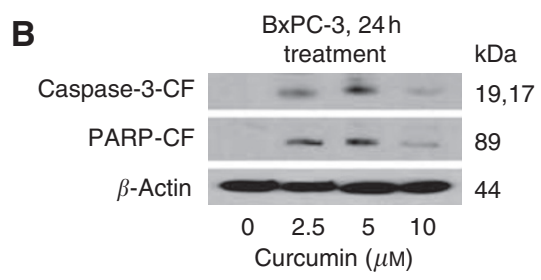

BxPC-3, 24h
treatment

Figure 2 Curcumin treatment causes DNA damage and induces apoptosis in BxPC-3 but not in normal HPDE-6 cells. BxPC-3 cells were treated with different concentrations of curcumin for $24 \mathrm{~h}$. Cells were lysed and the total lysate was prepared as described in the Materials and Methods. Representatives immunoblots show the effect of curcumin treatment in BxPC-3 cells on the expression or phosphorylation of H2A.X (Ser- I39), ChkI (Ser-280), DNA polymerase $\beta(\mathbf{A})$, cleaved fragments of caspase-3 and PARP (B), p-ATM (Ser-198I), p-ChkI (Ser-345), p-Cdc25C (Ser-2 I6) and protein expression of ATM, ChkI, Cdc25C, Cdkl, Cyclin BI (D). The effect of curcumin was also evaluated in normal HPDE-6 cells on p-H2A.X (Ser-I39), DNA polymerase $\beta$, full length and cleaved fragments of caspase-3 and PARP $(\mathbf{C})$. Each blot was stripped and reprobed with anti- $\beta$-actin antibody to ensure equal protein loading. Intensities of immunoreactive bands were quantified by densitometric scanning.

\section{Curcumin treatment modulates expression of G2/M cell cycle regulatory proteins}

DNA damage generally leads to the activation of the ATM/ATR pathway (Molinari, 2000; Abraham, 2001; Lukas et al, 2001; Huang et al, 2008). To further delineate the molecular mechanism of curcumin-mediated G2/M arrest, we determine its effect on the key-signaling proteins of this pathway. Treatment of BxPC- 3 cells with $2.5 \mu \mathrm{m}$ curcumin increased the phosphorylation of ATM at Ser-1981 without any change in the protein level. We did not observe any change in the phosphorylation of ATR at Ser- 428 or Chk2 at Thr-68 in curcumin-treated cells (data not shown). On the other hand, substantial phosphorylation of Chk1 at Ser-345 and Cdc25C at Ser-216 was observed in BxPC-3 cells treated with curcumin. For example, $2.5 \mu \mathrm{M}$ curcumin caused about 6 -fold phosphorylation of Chk1 at Ser-345 and 2 fold phosphorylation of Cdc25C at Ser-216 respectively when compared with their respective controls. Protein expression of Chk1 and Cdc25C, however, remained unaltered during the treatment (Figure 2D). The activation of Cdk1/Cyclin B1 complex is the rate-limiting factor for the cells to enter into mitosis, whereas its inactivation leads to G2/M arrest (Jackman et al, 2003). Exposure of BxPC-3 cells with $2.5 \mu \mathrm{M}$ curcumin for $24 \mathrm{~h}$ significantly reduced the expression of Cdk1 and Cyclin B1 as compared with DMSO-treated control cells (Figure 2D). These results suggest the possible involvement of ATM/Chk1/Cdc25C and downregulation of Cdk1 and cyclin B1 in curcumin-mediated G2/M cell cycle arrest.

\section{Silencing of ATM or Chk1 protein expression attenuate G2/M arrest and apoptosis by curcumin}

Next we raised a question whether activation of ATM or Chk1 by activating phosphorylation plays any direct role in curcumin- mediated cell cycle arrest and apoptosis. To address this question, we transiently transfected BxPC-3 cells with either ATM or Chk1SiRNA and then subjected the cells to curcumin treatment for $24 \mathrm{~h}$. Cells were then analysed for cell cycle distribution by flow cytometry and apoptosis by cell death detection ELISA assay. Our results demonstrate that silencing ATM or Chk1 expression completely prevents G2/M cell cycle arrest and protects the cells from curcumin-induced apoptosis (Figure 3A and B). However, it was rather surprising that transfection of cells with ATM-SiRNA alone significantly reduced the percentage of cells in G2/M phase. The explanation for this paradox is not clear at this point and warrants further investigation.

To further see whether blocking ATM or Chk1 activation can prevent the modulation of G2/M regulatory proteins by curcumin, cells were transfected with ATM or Chk1-SiRNA followed by treatment with $2.5 \mu \mathrm{M}$ curcumin for $24 \mathrm{~h}$. Our results show that silencing ATM significantly blocked curcumin-mediated activation of ATM at Ser-1981, Chk1 at Ser 345, Cdc25C at Ser 216 and modestly blocked the downregulation of the expression of Cdk1 and Cyclin B1 (Figure 4A). A substantial attenuation was observed in the cleavage of caspase- 3 and PARP in ATM-silenced curcumintreated cells as compared with curcumin treatment alone (Figure 4A).

Similar to ATM, silencing Chk1 by Chk1-specific SiRNA, curcumin-mediated phosphorylation of Chk1 at Ser-345 and $\mathrm{Cdc} 25 \mathrm{C}$ at Ser-216 was completely prevented (Figure $4 \mathrm{~B}$ ). The protein level of $\mathrm{Cdc} 25 \mathrm{C}$ remained unaltered whereas curcuminmediated downregulation of Cdk1 and cyclin B1 expression was substantially blocked and was equivalent to the control level (Figure 4B). In addition, cleavage of caspase-3 and PARP by curcumin was also significantly blocked in Chk1-silenced cells (Figure 4B). Taken together our results suggest the involvement of ATM/Chk1 in curcumin-mediated G2/M arrest and apoptosis. 
A

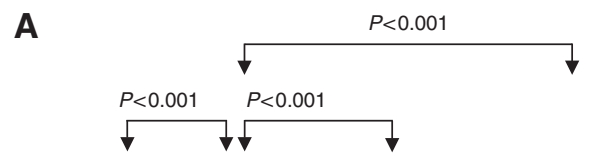

B

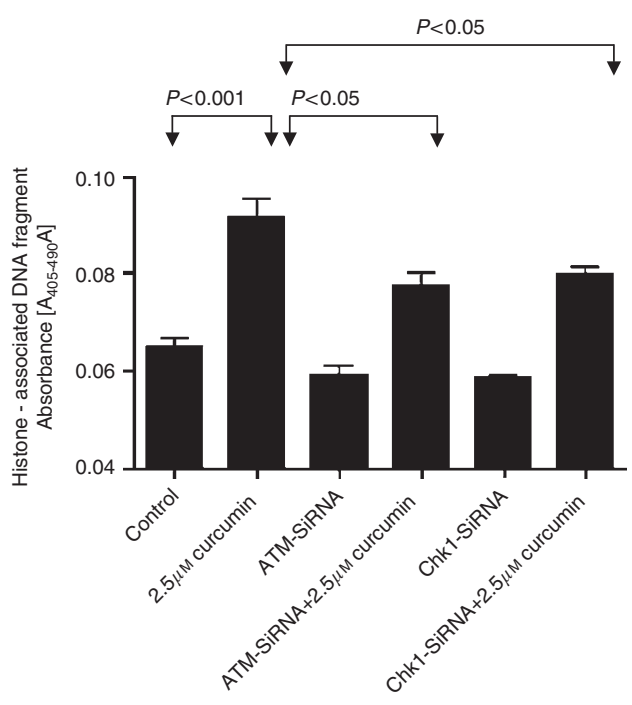

Figure 3 Role of ATM/Chkl in curcumin mediated G2/M cell cycle arrest and apoptosis. BXPC-3 cells were transiently transfected either with ATMSiRNA or ChkI-SiRNA followed by treatment with or without $2.5 \mu \mathrm{M}$ curcumin for $24 \mathrm{~h}$. Control cells received DMSO only. Cells were collected and analysed for cell cycle distribution by flow cytometry $(\mathbf{A})$. In a separate experiment, cells were plated in 96 well plates and transiently transfected either with ATM or ChkI-SiRNA followed by treatment with or without $2.5 \mu \mathrm{M}$ curcumin for $24 \mathrm{~h}$. Cells were lysed and analysed for apoptosis by the cell death detection ELISA method according to the manufacturer's protocol (B). The values are means \pm s.e.m. of 2 independent experiments (each conducted in triplicate). Data were analyzed by non-parametric ANOVA followed by Bonferroni's post hoc analysis for multiple comparisons. Differences between tested groups were analysed and considered significant at $P<0.05$ from control.

\section{DISCUSSION}

For maintenance of a normal cell cycle, cells possess cell cycle check points as control mechanisms to ensure proper execution of cell cycle events by protecting dividing cells from potentially fatal consequences of DNA damage (Singh and Khar, 2006; Tse et al, 2007). During DNA damage, cells are blocked in G2/M phase to provide time to repair damaged DNA (Molinari, 2000; Abraham, 2001 ), or lead to apoptotic cell death in case of severe DNA damage (Huang et al, 2008).

Several studies have indicated that curcumin induces cell cycle arrest and apoptosis in various human cancer cells (Park et al, 2006; Tan et al, 2006; Srivastava et al, 2007; Weir et al, 2007; Lin et al, 2008; Mackenzie et al, 2008; Sun et al, 2008). This study investigates the mechanism of DNA damage-mediated cell cycle arrest by curcumin in pancreatic cancer cells. We observed an increase in the phosphorylation of H2A.X at Ser-139, Chk1 at Ser-280 and a downregulation of the DNA polymerase- $\beta$ enzyme, indicating the presence of DNA double-strand breaks. On the other hand, normal HPDE-6 cells did not show any DNA damage incurred by curcumin treatment.

We demonstrate that curcumin treatment causes G2/M cell cycle arrest at a low concentration of $2.5 \mu \mathrm{M}$; whereas higher concentrations $(5-10 \mu \mathrm{M})$ of curcumin-induced extensive apoptosis in BxPC-3 cells as detected by cleavage of caspase- 3 and PARP. However, normal HPDE-6 cells were minimally affected by curcumin treatment even at concentrations that were highly toxic to BxPC-3 pancreatic cancer cells. The proximal transducer kinases ATM and ATR both possess the functional properties of a sensor. ATM is phosphoinositide 3-kinase-related kinases that play an important role in cell proliferation and DNA repair (Huang et al, 2008). DNA damage check points are predominantly associated with the activation of ATM whereas ATR is activated by stalling of the replication fork induced by UV, nucleotide imbalance, and DNA cross-linking (Lukas et al, 2001; Chen et al, 2008). During this process, ATM undergoes autophosphorylation on Ser-1981 and is recruited at the sites of DNA damage where it initiates a series of signaling cascades through the phosphorylation of multiple DNA damage response cell cycle proteins including Chk1 at Ser 345 and Ser 317/Chk2 at Thr-68 (Molinari, 2000; Abraham, 2001; Lukas et al, 2001). Our results clearly demonstrate the activation of ATM by phosphorylation at Ser-1981 by curcumin treatment. We, however, did not observe the activation of ATR by curcumin. These data are in line with the previous published study where kotomolide, a butanolide constituent isolated from the leaves of $\mathrm{C}$. kotoense induced cell cycle arrest and apoptosis through the activation of ATM in non-small cell lung cancer A549 cells (Huang et al, 2008). To show the involvement of ATM in curcumin-mediated cell cycle arrest, we selectively silenced the expression of ATM protein by ATM-specific SiRNAs. Silencing ATM expression significantly abrogated the activation of ATM at Ser-1981, Chk1 at Ser-345 and Cdc25C at Ser-216 in curcumin-treated cells and substantially prevented the cells from undergoing G2/M arrest and apoptosis.

Chk1, upon activation, phosphorylates Cdc25C at Ser-216 leading to inactivation of Cdk1-Cyclin B1 complex, which in turn leads to G2/M arrest (Molinari, 2000; Abraham, 2001; Lukas et al, 2001). Two check point kinases, Chk1 and Chk2, although being structurally different from each other in serine/threonine kinases, share overlapping functions (Jackman et al, 2003; HermanAntosiewicz and Singh, 2005; Sidi et al, 2008; Wang et al, $2008 \mathrm{a}, \mathrm{b})$. Over the past many years, an enormous effort has been made to gain insights into cell cycle checkpoint functions. Chk1 is an established transducer of ATR and ATM-dependent signaling in response to DNA damage. In addition to nuclear localisation, its presence on interphase centrosomes negatively regulates entry into mitosis by preventing premature activation of cyclin B-cdk1 complex during unperturbed cell cycles (Tyagi et al, 2005). In human cancers, dysfunction in this checkpoint is considered a serious pathologic hallmark of neoplastic transformation (Chen et al, 2008). Various chemotherapeutic agents and ionising radiation, which are used to treat cancer, have been shown to activate Chk1 (Chen et al, 2008). 

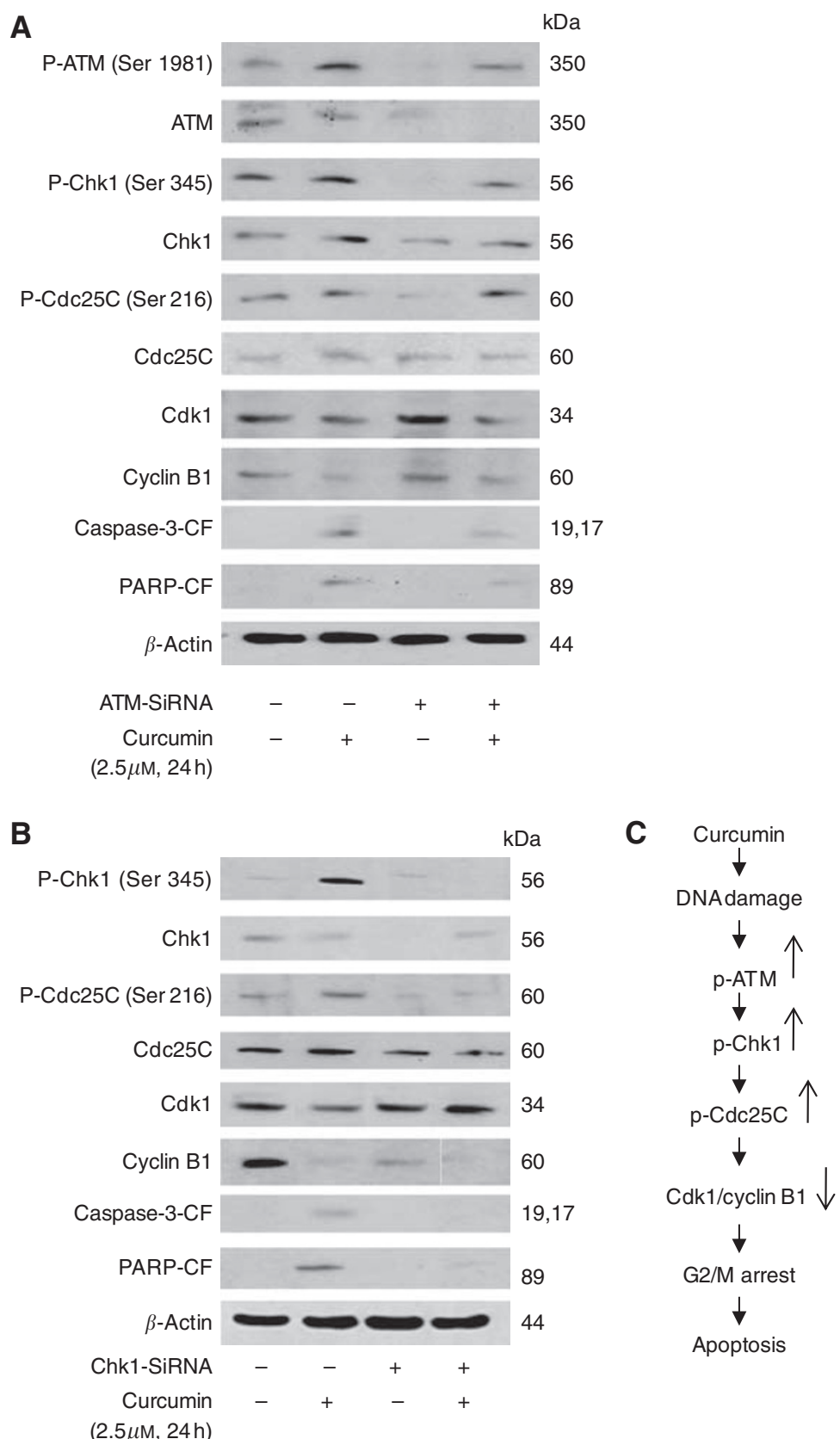

Figure 4 Involvement of ATM/ChkI in curcumin induced G2/M arrest and apoptosis. BxPC-3 cells were transiently transfected either with ATM-SiRNA (A) or ChkI-SiRNA (B) followed by treatment with or without $2.5 \mu \mathrm{M}$ curcumin for $24 \mathrm{~h}$. Control cells received DMSO only. Total cell lysates were prepared and samples were separated on I0\% SDS-PAGE. Samples were analysed to evaluate the expression of phospho-ATM (Ser-198I), Chk I (Ser-345), Cdc25C (Ser-2I6) and protein expression of ATM, Chk I, Cdc25C, CdkI, Cyclin BI and cleaved fragments of caspase-3 and PARP. Each blot was stripped and reprobed with anti- $\beta$-actin antibody to ensure equal protein loading. Intensities of immunoreactive bands were quantified by densitometric scanning. Possible mechanism by which curcumin induces G2/M arrest and apoptosis in BxPC-3 cells (C).

We observed significant activation of Chk1 by phosphorylation at Ser-345 with curcumin treatment. These results are in agreement with previous studies where diallyl trisulfide, resveratrol and lithium caused G2/M cell cycle arrest by activation of Chk1 in human prostate (Herman-Antosiewicz and Singh, 2005), ovarian (Tyagi et al, 2005) and hepatocellular (Wang et al, 2008a,b) carcinoma cells. However, no change in the activation of Chk1 at Ser-317 and Chk2 at Thr-68 was demonstrated by curcumin treatment. We further observed the phosphorylation of Cdc25C at Ser-216 and reduced expression of Cdk1/Cyclin B1 by curcumin treatment as shown earlier in other experimental models (Tyagi et al, 2005; Chen et al, 2008). To further strengthen the role of
Chk1 in G2/M regulation, Chk1 protein expression was specifically silenced in BxPC-3 cells by Chk1-SiRNAs. Silencing Chk1 expression significantly abrogated the activation of Chk1 at Ser-345, Cdc25C at Ser-216 and expression of Cdk1 and Cyclin B1 in curcumin-treated cells and substantially prevented the cells from undergoing G2/M arrest and apoptosis, suggesting that Chk1 plays an important role in curcumin-induced cell cycle arrest and apoptosis. Although our results are consistent with several published reports (Herman-Antosiewicz and Singh, 2005; Tyagi et al, 2005; Chen et al, 2008), a recent study made slightly conflicting observations. This study observed that abrogation of curcumin-mediated activation of Chk1 and G2/M cell cycle arrest 
induced apoptosis in hepatoma cells (Wang et al, 2008a,b). The reason for this discrepancy could be attributed to the cell-specific effect of curcumin. We found that the curcumin-mediated effect was specific to pancreatic cancer cells as the normal HPDE-6 cells show no change following curcumin treatment. On the basis of these findings, a possible mechanism by which curcumin induces $\mathrm{G} 2 / \mathrm{M}$ arrest and apoptosis in $\mathrm{BxPC}-3$ cells is summarised in Figure 4C.

Curcumin has been used in Asian countries as a dietary spice, a food-colouring agent and for the treatment of variety of ailments, including biliary disorder, anorexia, cough, diabetic wounds, hepatic disorders, rheumatism and sinusitis (Furukawa et al, 1996; Sharma et al, 2004). Although many in vitro studies have demonstrated the potential chemotherapeutic effects of curcumin against a variety of cancer cells, its clinical implementation has been a challenge because of its short half life and low bioavailability after oral administration (Cheng et al, 2001; Ireson et al, 2001; Singh and Khar, 2006). Cheng et al (2001) observed an average peak plasma concentration of $0.51-1.77 \mu \mathrm{M}$ $\left(188-652 \mathrm{ng} \mathrm{ml}^{-1}\right)$ after an oral administration of $4-8 \mathrm{~g}$ curcumin per day in patients with pre-malignant lesions. It is important to point out that the inhibitory concentration of $2.5 \mu \mathrm{M}$ curcumin in our model is very close to the clinically achievable plasma concentration of curcumin in humans suggesting its potential for the management of pancreatic cancer.

In addition to the effectiveness of curcumin alone, it is being currently evaluated in combination therapy (Koo et al, 2004; Kamat et al, 2007; Kunnumakkara et al, 2007; Lev-Ari et al, 2007; Patel et al, 2008). Kunnumakkara et al (2007) demonstrated that curcumin can potentiate the antitumour effects of gemcitabine by suppressing the proliferation and angiogenesis in an orthotopic model of pancreatic cancer. They observed that the ability of curcumin to decrease the expression of NF-kB-regulated gene products VEGF, Cyclin D1, c-Myc, ICAM-1, MMP-9, COX-2, survivin, Bcl-2, IAP1 and Bcl-xl in the tumours was enhanced in the combination treatment (Kunnumakkara et al, 2007). On the other hand, Lev-Ari et al (2006) showed that the antitumour activity of curcumin was associated with the decreased expression of EGFR, COX-2 and ERK in pancreatic cancer cells. These effects were pronounced in the cells P34-expressing COX-2 as compared with low COX-2-expressing Panc-1 cells (Lev-Ari et al, 2006).

Limited studies on curcumin in humans have been documented recently (Sharma et al, 2004; Dhillon et al, 2008). Sharma et al (2004), in a phase I clinical trial explored the pharmacology of curcumin in patients with colorectal cancer and suggested that curcumin could be used as an oral cancer preventive or therapeutic agent . Similarly, in a very recent study, Dhillon et al (2008) in a phase II clinical trial in patients with advanced pancreatic cancer concluded that $8 \mathrm{~g}$ of curcumin given orally was well tolerated and in spite of its limited absorption showed biological activity in some patients . Our preclinical studies also support these clinical studies on curcumin.

To conclude, our present observations state that curcumin treatment potentially inhibits the proliferation of $\mathrm{BxPC}-3$ human pancreatic cancer cells by DNA damage-mediated G2/M cell cycle arrest by the activation of ATM/Chk1/Cdc25C and inhibition of cyclin B1/Cdk1 expression. Our results indicate Chk1 as a novel molecular target of curcumin in pancreatic cancer cells. Nevertheless, further studies are needed to determine the mechanism of DNA damage and pinpoint other pivotal regulators of the signaling pathways mediated by curcumin in human pancreatic cancer cells.

\section{ACKNOWLEDGEMENTS}

This investigation was supported in part by USPHS RO1 Grant CA106953 (to SKS) awarded by the National Cancer Institute. The funds from Texas Tech University Health Sciences Center, School of Pharmacy and Hillman Foundation (to SKS) are also acknowledged. We thank Dr Ming-Sound Tsao, University of Toronto, Canada for providing normal immortal HPDE-6 cells, Dr Jim Luce for critically reading the paper and summer student Avisha Shah for technical assistance.

\section{REFERENCES}

Abraham RT (2001) Cell cycle checkpoint signaling through the ATM and ATR kinases. Genes Dev 15: 2177-2196

Aggarwal BB, Banerjee S, Bharadwaj U, Sung B, Shishodia S, Sethi G (2007) Curcumin induces the degradation of cyclin $\mathrm{E}$ expression through ubiquitin-dependent pathway and up-regulates cyclin-dependent kinase inhibitors p21 and p27 in multiple human tumor cell lines. Biochem Pharmacol 73: $1024-1032$

Ammon HP, Wahl MA (1991) Pharmacol Curcuma longa. Planta Med 57: 1-7

Aoki H, Takada Y, Kondo S, Sawaya R, Aggarwal BB, Kondo Y (2007) Evidence that curcumin suppresses the growth of malignant gliomas in vitro and in vivo through induction of autophagy: role of Akt and extracellular signal-regulated kinase signaling pathways. Mol Pharmacol 72: $29-39$

Bachmeier B, Nerlich AG, Iancu CM, Cilli M, Schleicher E, Vene R, Dell'Eva R, Jochum M, Albini A, Pfeffer U (2007) The chemopreventive polyphenol Curcumin prevents hematogenous breast cancer metastases in immunodeficient mice. Cell Physiol Biochem 19: 137-152

Banerjee M, Tripathi LM, Srivastava VM, Puri A, Shukla R (2003) Modulation of inflammatory mediators by ibuprofen and curcumin treatment during chronic inflammation in rat. Immunopharmacol Immunotoxicol 25: 213-224

Bharti AC, Donato N, Aggarwal BB (2003) Curcumin (diferuloylmethane) inhibits constitutive and IL-6-inducible STAT3 phosphorylation in human multiple myeloma cells. J Immunol 171: 3863-3871

Binion DG, Otterson MF, Rafiee P (2008) Curcumin inhibits VEGFmediated angiogenesis in human intestinal microvascular endothelial cells through COX-2 and MAPK inhibition. Gut 57: 1509-1517

Blasius R, Reuter S, Henry E, Dicato M, Diederich M (2006) Curcumin regulates signal transducer and activator of transcription (STAT) expression in K562 cells. Biochem Pharmacol 72: 1547-1554

Chen CY, Hsu YL, Tsai YC, Kuo PL (2008) Kotomolide A arrests cell cycle progression and induces apoptosis through the induction of ATM/p53 and the initiation of mitochondrial system in human non-small cell lung cancer A549 cells. Food Chem Toxicol 46: 2476-2484

Cheng AL, Hsu CH, Lin JK, Hsu MM, Ho YF, Shen TS, Ko JY, Lin JT, Lin BR, Ming-Shiang W, Yu HS, Jee SH, Chen GS, Chen TM, Chen CA, Lai MK, Pu YS, Pan MH, Wang YJ, Tsai CC, Hsieh CY (2001) Phase I clinical trial of curcumin, a chemopreventive agent, in patients with high-risk or pre-malignant lesions. Anticancer Res 21: 2895-2900

Deeb D, Jiang H, Gao X, Al-Holou S, Danyluk AL, Dulchavsky SA, Gautam SC (2007) Curcumin [1,7-bis(4-hydroxy-3-methoxyphenyl)-1-6heptadine-3,5-dione; $\mathrm{C} 21 \mathrm{H} 20 \mathrm{O} 6$ ] sensitizes human prostate cancer cells to tumor necrosis factor-related apoptosis-inducing ligand/Apo2Linduced apoptosis by suppressing nuclear factor-kappaB via inhibition of the prosurvival Akt signaling pathway. J Pharmacol Exp Ther 321: $616-625$

Dhillon N, Aggarwal BB, Newman RA, Wolf RA, Kunnumakkara AB, Abbruzzese JL, Ng CS, Badmaev V, Kurzrock R (2008) Phase II trial of curcumin in patients with advanced pancreatic cancer. Clin Can Res 14: 4491-4499

Fahey AJ, Adrian Robins R, Constantinescu CS (2007) Curcumin modulation of IFN-beta and IL-12 signalling and cytokine induction in human T cells. J Cell Mol Med 11: 1129-1137

Freudlsperger C, Greten J, Schumacher U (2008) Curcumin induces apoptosis in human neuroblastoma cells via inhibition of NFkappaB. Anticancer Res 28: 209-214

Furukawa T, Duguid WP, Rosenberg L, Viallet J, Galloway DA, Tsao MS (1996) Long-term culture and immortalization of epithelial cells from normal adult human pancreatic ducts transfected by the E6E7 gene of human papilloma virus 16. Am J Pathol 148: 1763-1770 
Goel A, Kunnumakkara AB, Aggarwal BB (2008) Curcumin as 'Curecumin': from kitchen to clinic. Biochem Pharmacol 75: 787-809

Hauser PJ, Han Z, Sindhwani P, Hurst RE (2007) Sensitivity of bladder cancer cells to curcumin and its derivatives depends on the extracellular matrix. Anticancer Res 27: 737-740

Herman-Antosiewicz A, Singh SV (2005) Checkpoint kinase 1 regulates diallyl trisulfide-induced mitotic arrest in human prostate cancer cells J Biol Chem 280: 28519-28528

Hidaka H, Ishiko T, Furuhashi T, Kamohara H, Suzuki S, Miyazaki M, Ikeda O, Mita S, Setoguchi T, Ogawa M (2002) Curcumin inhibits interleukin 8 production and enhances interleukin 8 receptor expression on the cell surface:impact on human pancreatic carcinoma cell growth by autocrine regulation. Cancer 95: 1206-1214

Huang M, Miao ZH, Zhu H, Cai YJ, Lu W, Ding J (2008) Chk1 and Chk2 are differentially involved in homologous recombination repair and cell cycle arrest in response to DNA double-strand breaks induced by camptothecins. Mol Cancer Ther 7: 1440-1449

Ireson C, Orr S, Jones DJ, Verschoyle R, Lim CK, Luo JL, Howells L, Plummer S, Jukes R, Williams M, Steward WP, Gescher A (2001) Characterization of metabolites of the chemopreventive agent curcumin in human and rat hepatocytes and in the rat in vivo, and evaluation of their ability to inhibit phorbol ester-induced prostaglandin E2 production. Cancer Res 61: $1058-1064$

Jackman M, Lindon C, Nigg EA, Pines J (2003) Active cyclin B1-Cdk1 first appears on centrosomes in prophase. Nat Cell Biol 5: 143-148

Jemal A, Murray T, Ward E, Samuels A, Tiwari RC, Ghafoor A, Feuer EJ, Thun MJ (2005) Cancer statistics, 2005. CA Cancer J Clin 55: 10-30

Ji C, Cao C, Lu S, Kivlin R, Amaral A, Kouttab N, Yang H, Chu W, Bi Z, Di W, Wan Y (2008) Curcumin attenuates EGF-induced AQP3 up-regulation and cell migration in human ovarian cancer cells. Cancer Chemother Pharmacol 62: $857-865$

Kamat AM, Sethi G, Aggarwal BB (2007) Curcumin potentiates the apoptotic effects of chemotherapeutic agents and cytokines through down-regulation of nuclear factor-kappaB and nuclear factor-kappaBregulated gene products in IFN-alpha-sensitive and IFN-alpha-resistant human bladder cancer cells. Mol Cancer Ther 6: 1022-1030

Kasinski AL, Du Y, Thomas SL, Zhao J, Sun SY, Khuri FR, Wang CY, Shoji M, Sun A, Snyder JP, Liotta D, Fu H (2008) Inhibition of IKK-NF\{kappa\}B signaling pathway by EF24, a novel monoketone analogue of curcumin. Mol Pharmacol 74: 654-661

Kim HY, Park EJ, Joe EH, Jou I (2003) Curcumin suppresses Janus kinaseSTAT inflammatory signaling through activation of Src homology 2 domain-containing tyrosine phosphatase 2 in brain microglia. J Immunol 171: $6072-6079$

Koo JY, Kim HJ, Jung KO, Park KY (2004) Curcumin inhibits the growth of AGS human gastric carcinoma cells in vitro and shows synergism with 5fluorouracil. J Med Food 7: 117-121

Kunnumakkara $A B$, Guha S, Krishnan S, Diagaradjane P, Gelovani J, Aggarwal BB (2007) Curcumin potentiates antitumor activity of gemcitabine in an orthotopic model of pancreatic cancer through suppression of proliferation, angiogenesis, and inhibition of nuclear factor-kappaB-regulated gene products. Cancer Res 67: 3853-3861

Lev-Ari S, Starr A, Vexler A, Karaush V, Loew V, Greif J, Fenig E, Aderka D, Ben-Yosef R (2006) Inhibition of pancreatic and lung adenocarcinoma cell survival by curcumin is associated with increased apoptosis, downregulation of COX-2 and EGFR and inhibition of Erk1/2 activity. Anticancer Res 26: $4423-4430$

Lev-Ari S, Vexler A, Starr A, Ashkenazy-Voghera M, Greif J, Aderka D, Ben-Yosef R (2007) Curcumin augments gemcitabine cytotoxic effect on pancreatic adenocarcinoma cell lines. Cancer Invest 25: $411-418$

Li L, Aggarwal BB, Shishodia S, Abbruzzese J, Kurzrock R (2004) Nuclear factor-kappaB and IkappaB kinase are constitutively active in human pancreatic cells, and their down-regulation by curcumin (diferuloylmethane) is associated with the suppression of proliferation and the induction of apoptosis. Cancer 101: 2351-2362

Lin SS, Huang HP, Yang JS, Wu JY, Hsai TC, Lin CC, Lin CW, Kuo CL, Gibson Wood W, Chung JG (2008) DNA damage and endoplasmic reticulum stress mediated curcumin-induced cell cycle arrest and apoptosis in human lung carcinoma A-549 cells through the activation caspases cascade- and mitochondrial-dependent pathway. Cancer Lett 272: $77-90$

Lin YG, Kunnumakkara AB, Nair A, Merritt WM, Han LY, Armaiz-Pena GN, Kamat AA, Spannuth WA, Gershenson DM, Lutgendorf SK, Aggarwal BB, Sood AK (2007) Curcumin inhibits tumor growth and angiogenesis in ovarian carcinoma by targeting the nuclear factorkappaB pathway. Clin Cancer Res 13: 3423-3430

Lukas C, Bartkova J, Latella L, Falck J, Mailand N, Schroeder T, Sehested M, Lukas J, Bartek J (2001) DNA damage-activated kinase Chk2 is independent of proliferation or differentiation yet correlates with tissue biology. Cancer Res 61: 4990-4993

Mackenzie GG, Queisser N, Wolfson ML, Fraga CG, Adamo AM, Oteiza PI (2008) Curcumin induces cell-arrest and apoptosis in association with the inhibition of constitutively active NF-kappaB and STAT3 pathways in Hodgkin's lymphoma cells. Int J Cancer 123: 56-65

Marín YE, Wall BA, Wang S, Namkoong J, Martino JJ, Suh J, Lee HJ, Rabson AB, Yang CS, Chen S, Ryu JH (2007) Curcumin downregulates the constitutive activity of NF-kappaB and induces apoptosis in novel mouse melanoma cells. Melanoma Res 17: 274-283

Miquel J, Bernd A, Sempere JM, Diaz-Alperi J, Ramirez A (2002) The curcuma antioxidants: pharmacological effects and prospects for future clinical use. A review. Arch Gerontol Geriatr 34: 37-46

Mitra A, Chakrabarti J, Banerji A, Chatterjee A, Das BR (2006) Curcumin, a potential inhibitor of MMP-2 in human laryngeal squamous carcinoma cells HEp2. J Environ Pathol Toxicol Oncol 25: 679-690

Molinari M (2000) Cell cycle checkpoints and their inactivation in human cancer. Cell Prolif 33: 261-274

Mukhopadhyay A, Bueso-Ramos C, Chatterjee D, Pantazis P, Aggarwal BB (2001) Curcumin downregulates cell survival mechanisms in human prostate cancer cell lines. Oncogene 20: 7597-7609

Ouyang H, Mou Lj, Luk C, Liu N, Karaskova J, Squire J, Tsao MS (2000) Immortal human pancreatic duct epithelial cell lines with near normal genotype and phenotype. Am J Pathol 157: 1623-1631

Park C, Kim GY, Kim GD, Choi BT, Park YM, Choi YH (2006) Induction of $\mathrm{G} 2 / \mathrm{M}$ arrest and inhibition of cyclooxygenase-2 activity by curcumin in human bladder cancer T24 cells. Oncol Rep 15: $1225-1231$

Patel BB, Sengupta R, Qazi S, Vachhani H, Yu Y, Rishi AK, Majumdar AP (2008) Curcumin enhances the effects of 5-fluorouracil and oxaliplatin in mediating growth inhibition of colon cancer cells by modulating EGFR and IGF-1R. Int J Cancer 122: 267-273

Reddy S, Rishi AK, Xu H, Levi E, Sarkar FH, Majumdar AP (2006) Mechanisms of curcumin- and EGF-receptor related protein (ERRP)-dependent growth inhibition of colon cancer cells. Nutr Cancer 55: $185-194$

Sahu RP, Srivastava SK (2009) The role of STAT-3 in the induction of apoptosis in pancreatic cancer cells by benzyl isothiocyanate. J Natl Can Inst 101: 176-193

Shankar S, Ganapathy S, Chen Q, Srivastava RK (2008) Curcumin sensitizes TRAIL-resistant xenografts: molecular mechanisms of apoptosis, metastasis and angiogenesis. Mol Cancer 7: 16

Shankar S, Srivastava RK (2007) Involvement of Bcl-2 family members, phosphatidylinositol $3^{\prime}$-kinase/AKT and mitochondrial p53 in curcumin (diferulolylmethane)-induced apoptosis in prostate cancer. Int $J$ Oncol 30: $905-918$

Sharma RA, Euden SA, Platton SL, Cooke DN, Shafayat A, Hewitt HR, Marczylo TH, Morgan B, Hemingway D, Plummer SM, Pirmohamed M, Gescher AJ, Steward WP (2004) Phase I clinical trial of oral curcumin biomarkers of systemic activity and compliance. Clin Cancer Res 10: $6847-6854$

Shi Y, Sahu RP, Srivastava SK (2008) Triphala inhibits both in vitro and in vivo growth of pancreatic tumor cells by inducing apoptosis. BMCCancer 8: 294

Shishodia S, Potdar P, Gairola CG, Aggarwal BB (2003) Curcumin (diferuloylmethane) down-regulates cigarette smoke-induced NF-kappaB activation through inhibition of IkappaBalpha kinase in human lung epithelial cells: correlation with suppression of COX-2, MMP-9 and cyclin D1. Carcinogenesis 24: 1269-1279

Sidi S, Sanda T, Kennedy RD, Hagen AT, Jette CA, Hoffmans R, Pascual J, Imamura S, Kishi S, Amatruda JF, Kanki JP, Green DR, D'Andrea AA, Look AT (2008) Chk1 suppresses a caspase-2 apoptotic response to DNA damage that bypasses $\mathrm{p} 53, \mathrm{Bcl}-2$, and caspase-3. Cell 133: $864-877$

Singh S, Khar A (2006) Biological effects of curcumin and its role in cancer chemoprevention and therapy. Anticancer Agents Med Chem 6: 259-270

Sinha R, Anderson DE, McDonald SS, Greenwald P (2003) Cancer risk and diet in India. J Postgrad Med 49: 222-228

Srivastava RK, Chen Q, Siddiqui I, Sarva K, Shankar S (2007) Linkage of curcumin-induced cell cycle arrest and apoptosis by cyclin-dependent kinase inhibitor p21(/WAF1/CIP1). Cell Cycle 6: 2953-2961 
Srivastava SK, Singh SV (2004) Cell cycle arrest and apoptosis-induced by benzyl isothiocyanate are associated with inhibition of nuclear factor kappa B activation in human pancreatic cancer cells. Carcinogenesis 25: $1701-1709$

Sun M, Estrov Z, Ji Y, Coombes KR, Harris DH, Kurzrock R (2008) Curcumin (diferuloylmethane) alters the expression profiles of microRNAs in human pancreatic cancer cells. Mol Cancer Ther 7: $464-473$

Tan TW, Tsai HR, Lu HF, Lin HL, Tsou MF, Lin YT, Tsai HY, Chen YF, Chung JG (2006) Curcumin-induced cell cycle arrest and apoptosis in human acute promyelocytic leukemia HL-60 cells via MMP changes and caspase-3 activation. Anticancer Res 26: $4361-4371$

Tse AN, Carvajal R, Schwartz GK (2007) Targeting checkpoint kinase 1 in cancer therapeutics. Clin Cancer Res 13: $1955-1960$

Tyagi A, Singh RP, Agarwal C, Siriwardana S, Sclafani RA, Agarwal R (2005) Resveratrol causes Cdc2-tyr15 phosphorylation via ATM/ATR-Chk1/2Cdc25C pathway as a central mechanism for S phase arrest in human ovarian carcinoma Ovcar-3 cells. Carcinogenesis 26: 1978-1987

Wahl H, Tan L, Griffith K, Choi M, Liu JR (2007) Curcumin enhances Apo2L/TRAIL-induced apoptosis in chemoresistant ovarian cancer cells. Gynecol Oncol 105: 104-112
Wang W-Z, Cheng J, Luo J, Zhuang S-M (2008a) Abrogation of G2/M arrest sensitizes curcumin-resistant hepatoma cells to apoptosis. FEBS Lett 582: $2689-2695$

Wang XM, Li J, Feng XC, Wang Q, Guan DY, Shen ZH (2008b) Involvement of the role of Chk1 in lithium-induced G2/M phase cell cycle arrest in hepatocellular carcinoma cells. J Cell Biochem 104: 1181-1191

Wang Z, Zhang Y, Banerjee S, Li Y, Sarkar FH (2006) Notch-1 downregulation by curcumin is associated with the inhibition of cell growth and the induction of apoptosis in pancreatic cancer cells. Mol Cancer Ther 106: $2503-2513$

Weir NM, Selvendiran K, Kutala VK, Tong L, Vishwanath S, Rajaram M, Tridandapani S, Anant S, Kuppusamy P (2007) Curcumin induces G2/M arrest and apoptosis in cisplatin-resistant human ovarian cancer cells by modulating Akt and p38 MAPK. Cancer Biol Ther 6: 178-184

Zhang R, Humphreys I, Sahu RP, Shi Y, Srivastava SK (2008) In vitro and in vivo induction of apoptosis by capsaicin in pancreatic cancer cells is mediated through ROS generation and mitochondrial death pathway. Apoptosis 13: $1465-1478$

Zhang R, Loganathan S, Humphreys I, Srivastava SK (2006) Benzyl isothiocyanate-induced DNA damage causes G2/M cell cycle arrest and apoptosis in human pancreatic cancer cells. J Nutr 136: 2728-2734 